\title{
Sistem Monitoring Lulusan Perguruan Tinggi Dalam Memasuki Dunia Kerja Menggunakan Tracer Study
}

\author{
Kusno Harianto, Heny Pratiwi, Yonatan Suhariyadi \\ STMIK Widya Cipta Dharma \\ Jl. Prof. M. Yamin No.25 Samarinda Kalimantan Timur, (0541)736071 \\ dzakiraharianto97@gmail.com,henypratiwi@wicida.ac.id
}

\begin{abstract}
This research is titled Monitoring System of Higher Education Graduates in Entering the World of Work Using Tracer Study. The problem raised in this study is that the BKK (Bursa Kerja Khusus) STMIK Widya Cipta Dharma Samarinda get information about the performance of STMIK graduate students Widya Cipta Dharma, analyze graduate data to obtain the relevance of the competency of STMIK graduates Widya Cipta Dharma Samarinda, change the old system into a system that new. The purpose of this research is to provide information and reports on the results of tracer study data collection from alumni of STMIK Widya Cipta Dharma Samarinda. Data collection methods used are literature study, field studies. The system development method used is the waterfall method. Informatic System of Alumnus Record Tracer Study Based Website of STMIK Widya Cipta Dharma Samarinda is a computer-based system that was built with the aim of processing the alumnus search to find out the description of the profile, performance, and distribution of work location of the alumnus. Informatic System of Alumnus Record Tracer Study Based Website of STMIK Widya Cipta Dharma Samarinda is expected to help assist the BKK (Bursa Kerja Khusus) in recording alumnus and record the track record of alumnus scattered in serveral areas.
\end{abstract}

Keywords: Monitoring System, Tracer Study.

\begin{abstract}
Abstrak
Penelitian ini berjudul Sitem Monitoring Lulusan Perguruan Tinggo Dalam memasuki Dunia Kerja Menggunakan Tracer Study. Masalah yang diangkat pada penelitian ini adalah agar BKK (Bursa Kerja Khusus) STMIK Widya Cipta Dharma Samarinda mendapatkan informasi tentang kinerja mahasiswa lulusan STMIK Widya Cipta Dharma, menganalisis data lulusan untuk memperoleh relevansi kompetensi lulusan STMIK Widya Cipta Dharma Samarinda, mengubah sistem lama manjadi sistem yang baru. Tujuan dari penelitian ini adalah menyediakan informasi dan laporan hasil pendataan tracer study dari para alumni STMIK Widya Cipta Dharma Samarinda. Metode pengumpulan data yang digunakan adalah studi pustaka, studi lapangan. Metode pengembangan pengembangan sistem yang digunakan adalah metode waterfall. Sistem Informasi Penelusuran Alumni (Tracer Study) Pada STMIK Widya Cipta Dharma Samarinda Berbasis Website adalah sebuah sistem berbasis komputer yang dibangun dengan tujuan memproses penelusuran para alumni guna mengetahui gambaran tentang profil, kinerja, serta sebaran lokasi kerja para alumni yang dapat membantu BKK (Bursa Kerja Khusus) dalam melakukan pencatatan alumni dan mencatat track record alumni yang tersebar di beberapa wilayah.
\end{abstract}

Kata Kunci : Sistem Monitoring, Tracer Study.

\section{PENDAHULUAN}

Tracer Study atau yang sering disebut sebagai server alumni atau survey "follow up" adalah studi mengenai lulusan lembaga penyelenggaraan pendidikan tinggi. Studi ini mampu menyediakan berbagai informasi yang 
bermanfaat bagi kepentingan evaluasi hasil pendidikan tinggi dan selanjutnya dapat digunakan untuk penempurnaan dan penjaminan kualitas lembaga pendidikan tinggi yang bersangkutan. Tracer Studi juga bermanfaat dalam menyediakan informasi penting mengenai hubungan antara pendidikan tinggi dan dunia kerja professional, menilai relevansi pendidikan tinggi, informasi bagi pemangku kepentingan (stakeholders), dan kelengkapan persyaratan bagi akreditasi pendidikan tinggi. Perguruan tinggi perlu melaksanakan Tracer Study karena membutuhkan umpan balik dari alumni dalam usahanya untuk perbaikan sistem dan pengelolaan pendidikan [1].

Studi penelusuran alumni merupakan proses penelusuran para alumni guna mengetahui gambaran tentang profil, kinerja, serta sebaran lokasi kerja para alumni. Selain itu bagi suatu perguruan tinggi, studi penelusuran alumni yang selanjutnya akan disebut tracer study dapat digunakan untuk mengetahui keberhasilan proses pendidikan terhadap anak didiknya, dan juga sebagai indikator keberhasilan pendidikan yang diselenggarakan perguruan tinggi itu sendiri. Sekolah Tinggi Manajemen Informatika Dan Komputer Widya Cipta Dharma (STMIK WICIDA) merupakan salah satu perguruan tinggi yang melakukan studi penelusuran alumni. Belum adanya proses pengolahan data yang tetap, penelusuran alumni selama ini hanya dilaksanakan pada saat akreditasi kampus, sehingga data yang dikumpulkan dan di olah berdasarkan data yang akan diisi pada borang akreditasi, seperti data dikelompokkan berdasarkan tahun kelulusan. Selain itu, penyimpanan data alumni masih dilakukan secara manual sehingga menimbulkan data yang bertumpuk. Serta masalah pencarian data alumni yang masih sulit dilakukan karena harus mencari data yang bertumpuk sehingga membutuhkan waktu yang cukup lama. Sehubungan dengan hal tersebut, untuk lebih mempermudah studi penelusuran alumni di STMIK Widya Cipta Dharma Samarinda, maka peneliti melakukan penelitian tentang "sistem monitoring lulusan perguruan tinggi dalam dunia kerja menggunakan tracer study" sistem informasi yang dapat mengumpulkan dan mengelola serta menyajikan data dari para alumni.

\section{METODOLOGI PENELITIAN}

Bahan-bahan dan metode yang akan digunakan dalam membuat sistem ini adalah sebagai berikut:

\subsection{Unified Modeling Language (UML)}

UML sebuah "bahasa" yang menjadi standar dalam industry untuk visualisasi, merancang dan mendokumentasikan sistem piranti lunak. UML menawarkan sebuah standar untuk merancang model sebuah sistem" [2]. Permodelan (modelling) adalah proses merancang piranti lunak sebelum melakukan pengkodean (coding) [2]. Ada 4 (empat) macam diagram dalam Unified Modeling Diagram (UML) yaitu : 
1. Use Case Diagram

Use Case Diagram merupakan pemodelan untuk menggambarkan kelakuan (Behavior) sistem yang akan dibuat.

2. Class Diagram

Class Diagram menggambarkan struktur sistem dari segi pendefinisian kelas-kelas yang akan dibuat untuk membangun sistem.

3. Activity Diagram

Activity Diagram merupakan state diagram khusus, dimana sibagaian besar state adalah action dan sebagian besar transisi di-trigger oleh selesainya state sebelumnya (internal processing).

4. Sequance Diagram

Sequance Diagram menggambarkan kelakuan/prilaku objek pada use cae dengan mendeskripsikan waktu hidup objek dan pesan yang dikirimkan dan diterima antara objek.

\subsection{Metode Waterfall}

Waterfall pada umumnya digunakan untuk rekayasa sistem yang besar dimana proyek dikerjakan di beberapa tempat berbeda dan dibagi menjadi beberapa $s u b$ proyek [3]. Tahapan-tahapan yang terdapat dalam Waterfall [3] adalah sebagai berikut:

a) Requirements Definition : mengumpulkan kebutuhan secara lengkap kemudian dianalisis dan didefinisikan kebutuhan yang harus dipenuhi oleh program yang akan dibagun.

b) System and Software Design : desain dikerjakan setelah kebutuhan selesai dikumpulkan secara lengkap.

c) Implementation and Unit Testing : desain program diterjemahkan ke dalam kode-kode dengan menggunakan bahasa pemograman yang sudah ditentukan.

d) Integration and System Testing : penyatuan unit-unit program kemudian diuji secara keseluruhan (sistem testing).

e) Operation and maintenance : mengoperasikan program dilingkungannya dan melakukan pemeliharaan,

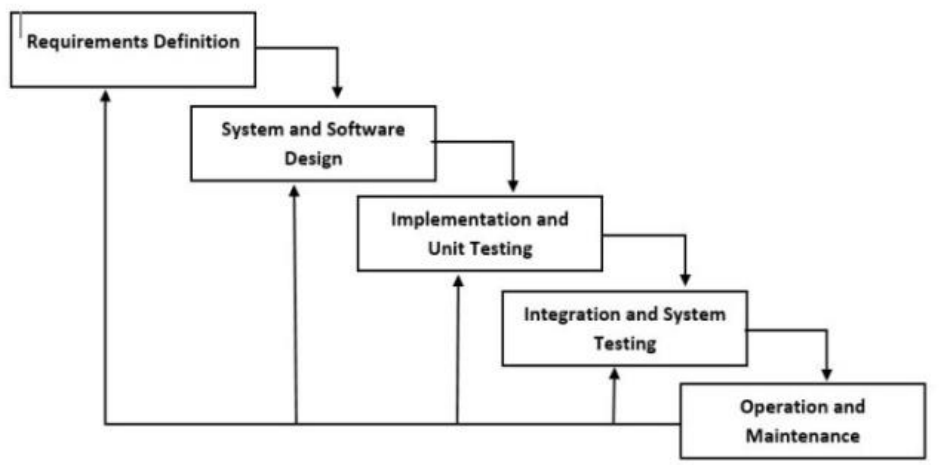

Gambar 1. Fase-Fase dalam waterfall model 


\subsection{Pengujian Sistem}

Pengujian perangkat lunak adalah: "elemen kritis dari jaminan perangkat lunak dan mempresentasikan kajian pokok dari spesifikasi, desain dan pengodean [4].

\subsubsection{Pengujian Black Box Testing}

Pengujian kotak hitam (black-box testing) dirancang untuk memvalidasi persyaratan fungsional tanpa perlu mengetahui kerja internal dari sebuah program. Teknik pengujian black box testing berfokus pada informasi dari perangkat lunak, menghasilkan test case dengan cara mempartisi masukan dan keluaran dari sebuah program dengan cara mencakup pengujian yang menyeluruh.

\subsubsection{Pengujian Beta}

Pada jenis pengujian ini, perangkat lunak didistribusikan sebagai sebuah versi beta dengan pengguna yang menguji aplikasi di situs mereka. Pengujian beta ini dilakukan dengan cara melakukan pengujian kuisioner yang dibagikan kepada beberapa responden yang merupakan target pengguna (User Target) [5].

\subsection{Lokasi Penelitian}

Penelitian "sistem monitoring lulusan perguruan tinggi dalam dunia kerja menggunakan tracer study" akan dilaksanakan di Kampus STMIK Widya Cipta Dharma Samarinda, Jl. M. Yamin, Gn. Kelua, Kec. Samarinda Ulu, Kalimantan Timur, 75123.

\section{HASIL DAN PEMBAHASAN}

\subsection{Requirement Definition}

Tujuan dari requirement definition adalah mendifinisikan format dan kebutuhan software. Analisa adalah tahap awal yang harus dilakukan untuk mengidentifikasi berbagai permasalahan yang ada pada sistem serta kebutuhan bagi pemakainya.

\subsection{Analisis Data}

Pada perancangan sistem informasi penelusuran alumni (tracer study) web, didapatkan analisis data apa saja yang nantinya akan diproses baik sebagai masukan maupun keluarannya. Data yang didapatkan antara lain :

1) Data Alumni, berisi tentang data alumni yang pernah melakukan perkuliahan dari awal sampai dengan menuntaskan perkuliahan dari semester awal sampai dengan lulus dari STMIK Widya Cipta Dharma Samarinda.

2) Data Kuisioner Alumi, berisi tentang data track record alumni setelah lulus dari perguruan tinggi.

3) Data Kuisioner Penilaian Stakeholder, berisi tentang data pengguna alumni tentang penilaian alumni lulusan perguruan tinggi STMIK Widya Cipta Dharma yang berkerja pada pengguna alumni disajikan untuk memperlihatkan presentasi data dalam bentuk grafik. 


\subsection{System and Software Design}

Tahapan ini bertujuan untuk memberikan gambaran secara garis besar sistem yang akan dibagun, dan juga mudah kan untuk memahami jalannya sistem, dan juga pemahaman pada jalannya program, alat bantu desain yang digunakan adalah Unified Modelling Language (UML) yang terdiri dari UseCase Diagram, Activity Diagram, Sequence Diagram dan Class Diagram sebagai berikut:

\subsubsection{Use case Diagram User}

Dari gambar 2 merupakan prosedur rancangan sistem yang memiliki 3 (tiga) entitas atau aktor yaitu Alumni, Stakeholder Admin. Alumni dapat melakukan Pendaftaran, login sistem, mengisi biodata, mengisi kuisoner, update kuisioner, dan melakukan update password dan profil dari menu profil. Stakeholder dapat melakukan registrasi, login sistem, mengisi kuisioner stakeholder, update kuisioner stakeholder, Admin dapat melakukan Login sistem, input berita, input gambar slideshow, melihat user alumni, melihat data isian kuisoner alumni, melihat data berdasarkan grafik, cetak laporan, dan melakukan update password dan profil dari menu profil.

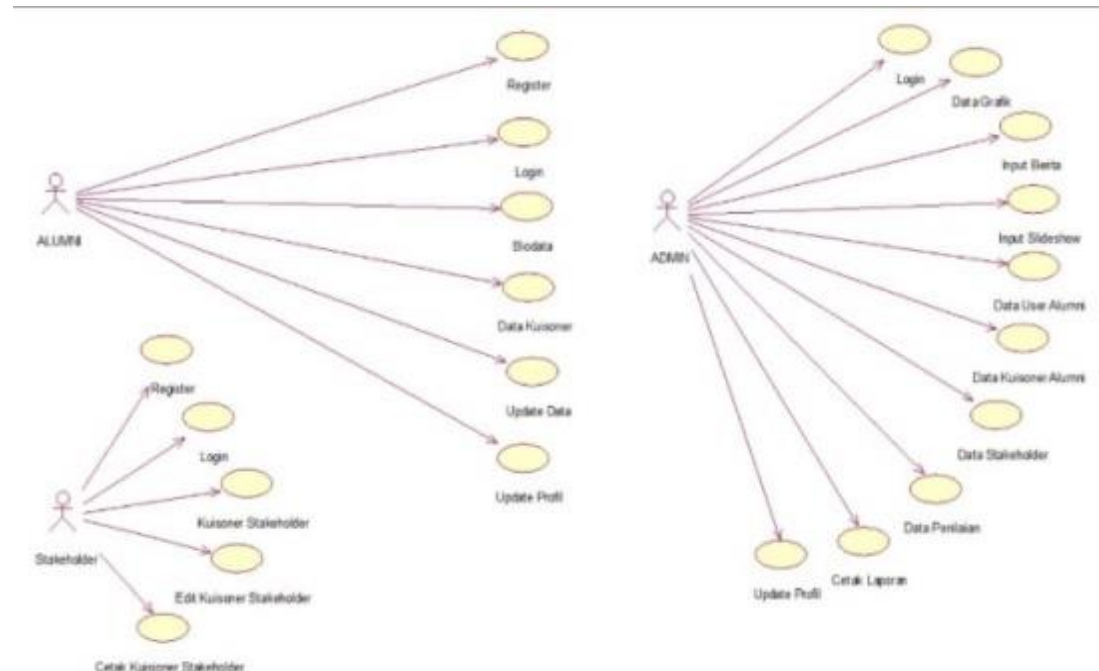

Gambar 2. UseCase Diagram Tracer study

\subsubsection{Activity Diagram Register Alumni}

Pada gambar 3 menggambarkan bagaimana seorang alumni jika ingin menjadi user harus melakukan registrasi pada sistem yang dimana didalam Registrasi mencakup proses Register, pengisian biodata, pengisian kuisoner tracer study. Dimana alumni mengakses alamat url dari website tracer study, kemudian saat di halaman beranda alumni mengakses menu register alumni, lalu alumni mengisi formregistrasi dan mengklik tombol register, setelah melakukan register maka alumni akan di arahkan ke halaman pengisian biodata yang dimana alumni diminta untuk mengisi biodata diri alumni agar dapat melanjutkan untuk mengisi kuisoner satu, jika sudah mengisi biodata dan dianggap data yang di inputkan sudah sebenar-benar nya maka klik 
submit, jika merasa ingin mereset semua fom isian dari form inputkan maka klik reset.Selanjutnya alumni akan di arahkan ke halaman pengisian kuisoner satu dengan metode pengisian yang hampir sama seperti pengisian biodata sebelum nya jika sudah melakukan semua seperti yang telah dijelaskan maka alumni akan langsung di arahkan ke halaman utama. Proses lebih jelas nya akan di tampilkan pada gambar 3 sebagai berikut:

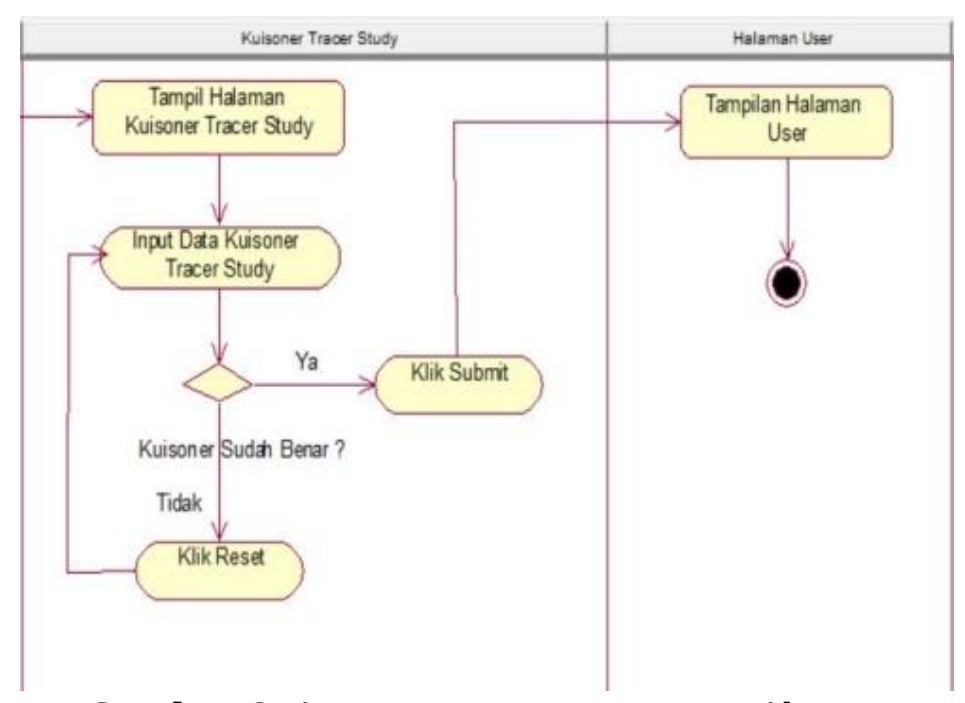

Gambar 3. Activity Diagram Register Alumni

\subsubsection{Activity Diagram Proses Kuisioner Tracer Study}

Pada gambar 4 menggambarkan bagaimana seorang alumni jika ingin melakukan proses pengisian kuisoner karena di saat Register proses yang di gambarkan tidak bisa dalam 1 diagram maka diagram kuisoner satu di buat lebih detail untuk mengetahui proses nya, di saat Register pada saat pengisian kuisoner satu pertama-tama di form kuisioner tracer study alumni akan di berikan pertanyaan kapan alumni mencari pekerjaan dengan tiga jawaban sebelum lulus, setelah lulus, dan saya tidak mencari pekerjaan jika alumni memilih jawaban sebelum lulus dan setelah lulus maka lanjutan kuisoner akan langsung mengarah ke form 1 (satu)yang harus di isi alumni tetapi jika alumni memilih saya tidak mencari pekerjaan maka akan langsung ke form 2 (dua), kemudian di form 2 (dua) alumni akan diberikan pertanyaan apakah alumni sedang berkerja dengan jawaban ya atau tidak, jika alumni memilih jawaban ya maka alumni harus mengisi form 2 (dua) tetapi jika tidak maka alumni akan langsung mengarah pada pengisian form 3 (tiga). Saat di pengisian kuisoner tracer study dan form 1 (satu) jika alumni sudah selesai mengisi data kuisoner tracer studydan form 1 (satu) dan klik submit maka proses pengisian kuisoner satu selesai, sama seperti form 1(satu) saat di pengisian form 2 (dua) dan form 3 (tiga) jika sudah mengisi data kuisoner dan klik submit maka semua rekap data kuisoner tracer study dari form yang telah di pilih oleh alumni akan langsung tersimpan kedalam database. Proses detail digambarkan pada gambar 4 sebagai berikut : 
Jurnal Sains Komputer \& Informatika (J-SAKTI)

Volume 3 Nomor 2 September 2019, pp. 295-306

ISSN:2548-9771/EISSN:2549-7200

http://tunasbangsa.ac.id/ejurnal/index.php/jsakti
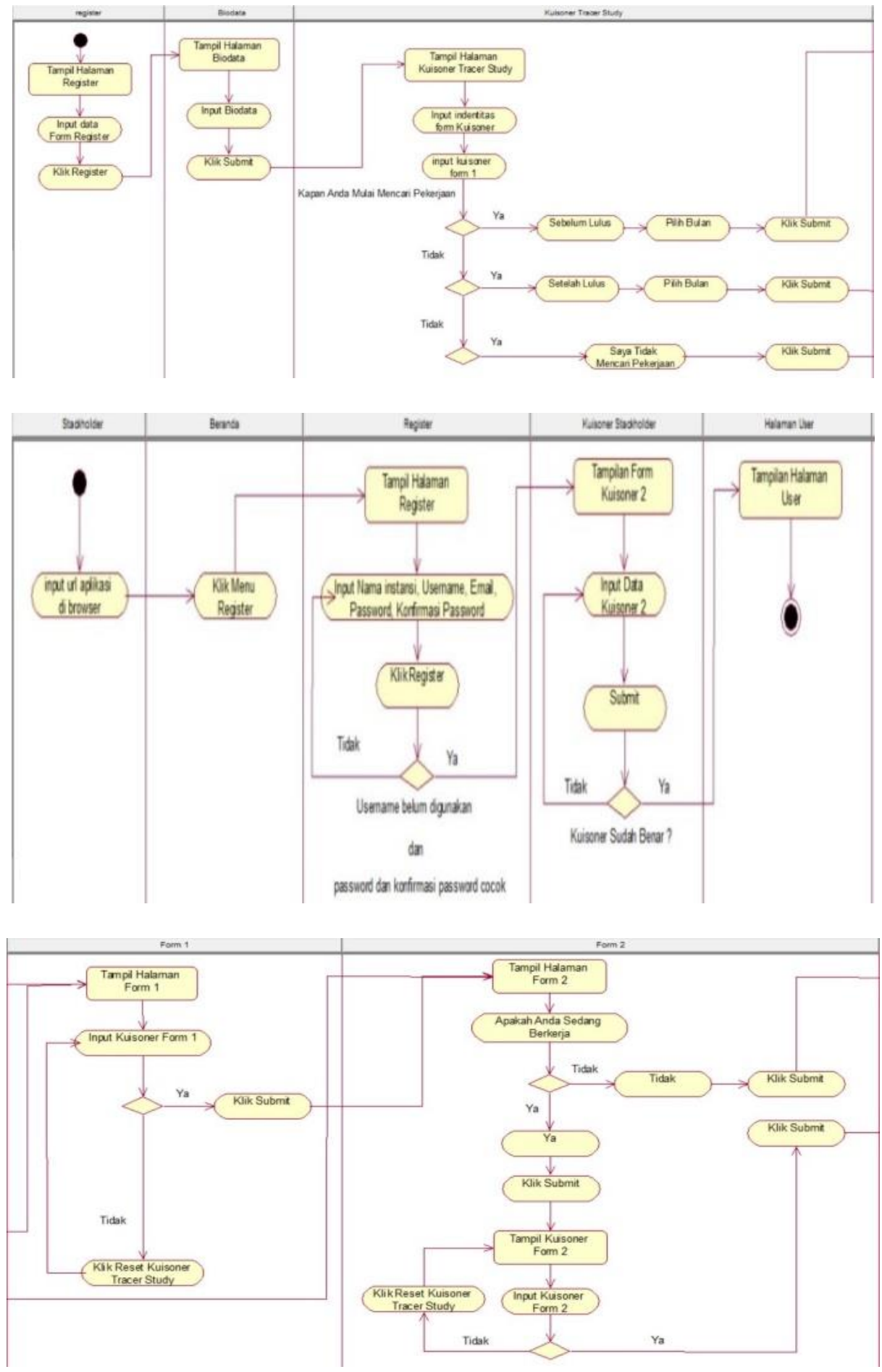


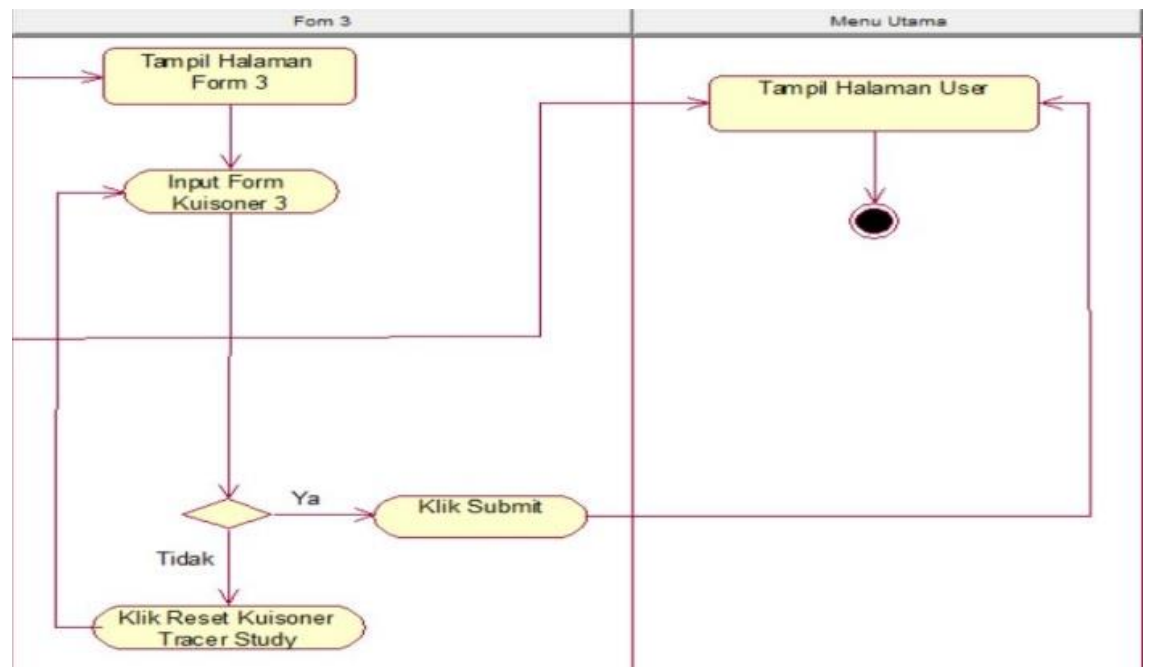

Gambar 4. Activity Diagram Kuisioner Tracer study

\subsubsection{Activity Diagram Menu User Alumni}

Pada gambar 5 menggambarkan menu yang dapat di akses oleh alumni pada website Tracer study, alumni harus melakukan login sistem dengan username dan password yang telah terdaftar didalam website Tracer study, kemudian setelah login alumni akan mendapatkan beberapa menu yang dapat di akses sebagai mana fungsinya, dimana menu biodata berguna untuk mengupdate biodata, menu kuisoner satu untuk meng-reset kuisoner satu yang telah di input, menu kuisoner dua untuk mengubah atau memperbahrui data kuisoner dua, kemudian menu profil dimana digunakan untuk mengubah username dan password yang alumni miliki. Proses detail digambarkan pada gambar 5 sebagai berikut:

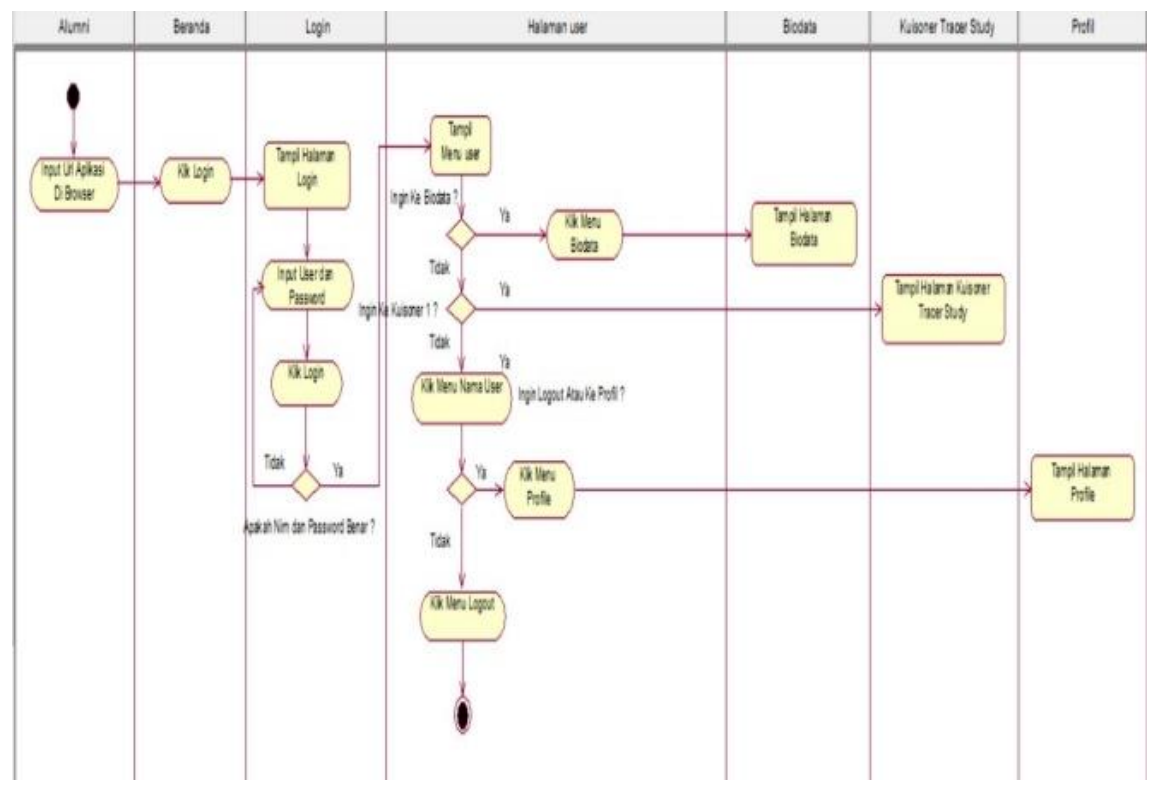

Gambar 5. Activity Diagram Menu User Alumni 


\subsubsection{Sequence Diagram Login}

Pada gambar 6 sequence diagram login pertama-tama alumni dan admin mengakses alamat website Tracer study, kemudian tampil halaman beranda Tracer study, selanjutnya admin dan alumni mengakses menu login maka akan tampil halaman form login, alumni dan admin di minta untuk menginputkan username dan password lalu klik login, kemudian sistem akan mengecek database apakah username dan password benar atau tidak, jika tidak maka proses input username dan password akan kembali terulang namun jika benar maka alumni dan admin akan di alihkan ke halaman user berdasarkan role dari masing-masing user.Proses detail digambarkan pada gambar 6 sebagai berikut :

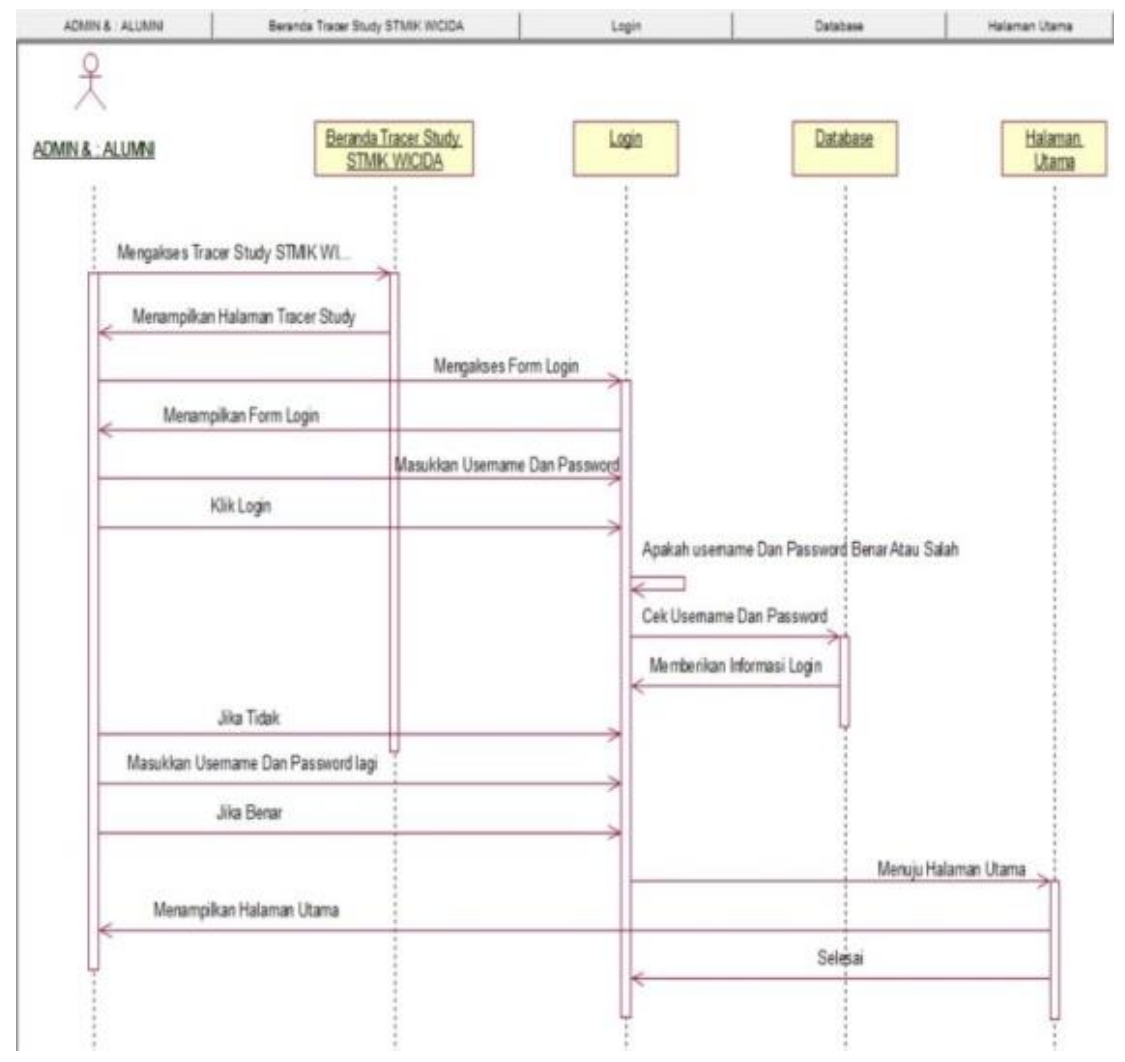

Gambar 6. Sequence Diagram Login

\subsubsection{Class Diagram Program Tracer Study}

Pada gambar 6 Class Diagram Tracer study terdapat 11 (sebelas) tabel yang saling berelasi satu sama lain. Pada tabel user dapat dilakukan proses view, insert, update dan delete. Pada tabel mahasiswa dapat dilakukan proses view, insert, update. Pada tabel form dapat dilakukan proses insert. Pada tabel identitas dapat dilakukan proses view,insert, updatedan delete. Pada tabel jawaban dapat dilakukan proses view, insert, update dan delete. Pada tabel pilihan dapat dilakukan proses view, insert dan update. Pada tabel form terisi dapat dilakukan proses insert dan delete. Pada tabel kuisoner dua dapat 
dilakukan proses view, insert, update dan delete.Pada tabel proses kuisoner dapat dilakukan proses insert saja. Pada tabel berita dapat dilakukan proses view, insert, update dan delete. Pada tabel slideshow dapat dilakukan proses view, insert dan delete.Proses detail digambarkan pada gambar 7 sebagai berikut :

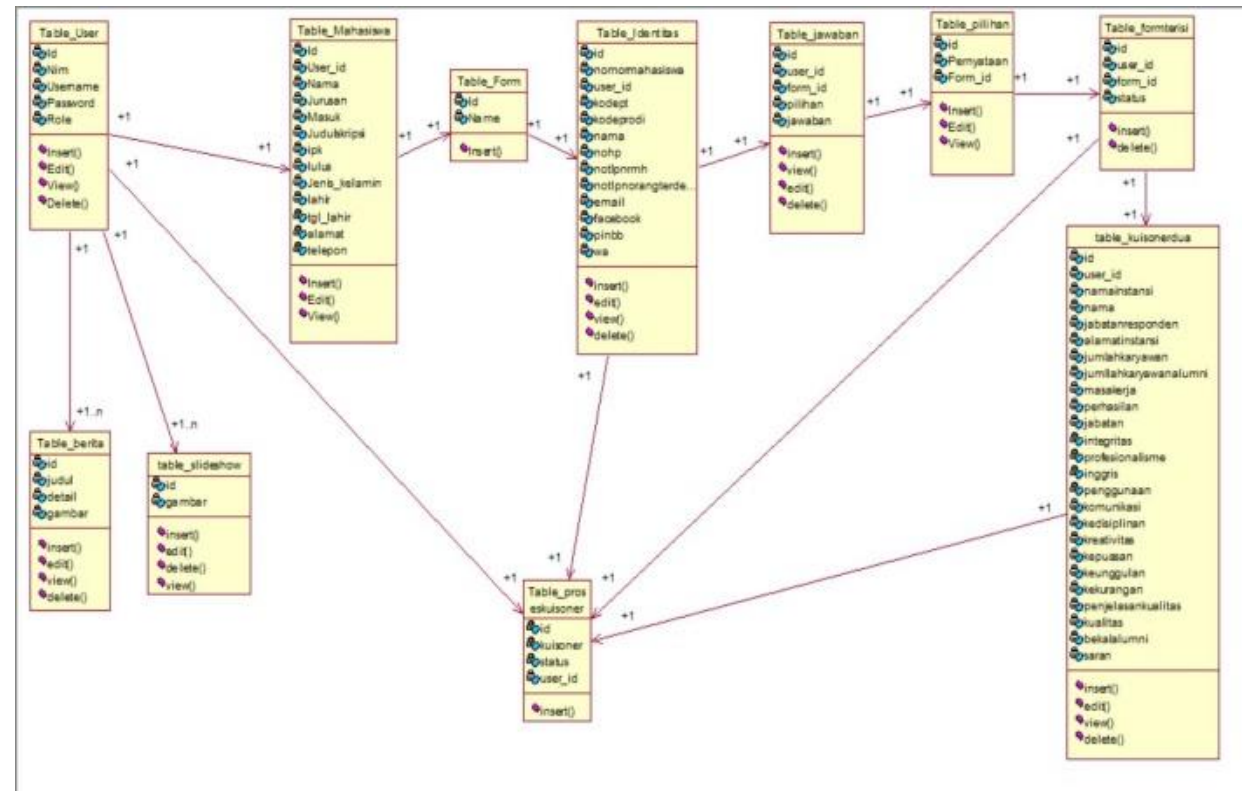

Gambar 7. Class Diagram Program Tracer study

\subsection{Database}

Rancangan database dari sistem tracer study adalah seperti berikut:

a) Tabel User

Nama Tabel : users

Primary Key : username

Keterangan : Menyimpan user alumni dan stakeholder yang akan login pada sistem tracer study.

Tabel 1. Tabel User

\begin{tabular}{|c|c|c|c|c|}
\hline No & Field & Type & Size & Keterangan \\
\hline 1 & id & Integer & 10 & Kode Urutan \\
\hline 2 & kuisioner & Varchar & 50 & Nama User \\
\hline 3 & status & Varchar & 50 & Akun User \\
\hline 4 & User_id & Integer & 10 & Alamat Email \\
\hline
\end{tabular}

b) Tabel Proses Kuisioner

Nama Tabel : proses kuisioner

Primary Key : id

Keterangan : Menyimpan rekap apakah user telah selesai mengisi proses kuisoner atau masih dalam proses pengisian. 
Tabel 2. Proses Kuisoner

\begin{tabular}{|c|c|c|c|c|}
\hline No & Field & Type & Size & Keterangan \\
\hline 1 & id & Integer & 10 & Kode Urutan \\
\hline 2 & kuisioner & Varchar & 50 & Nama User \\
\hline 3 & status & Varchar & 50 & Akun User \\
\hline 4 & User_id & Integer & 10 & Alamat Email \\
\hline
\end{tabular}

\subsection{Implementation Website Tracer Study}

Tahapan ini merupakan implementasi dari sistem yang telah dianalisis ke dalam bentuk perangkat lunak. Peneliti membuat program dengan hasil seperti berikut ini:

\section{a) Tampilan Halaman Beranda}

Pada gambar 8 tampilan dari halaman beranda pada sebagai tampilan awal pada saat website tracer study pertama kali diakses oleh Masyarakat.

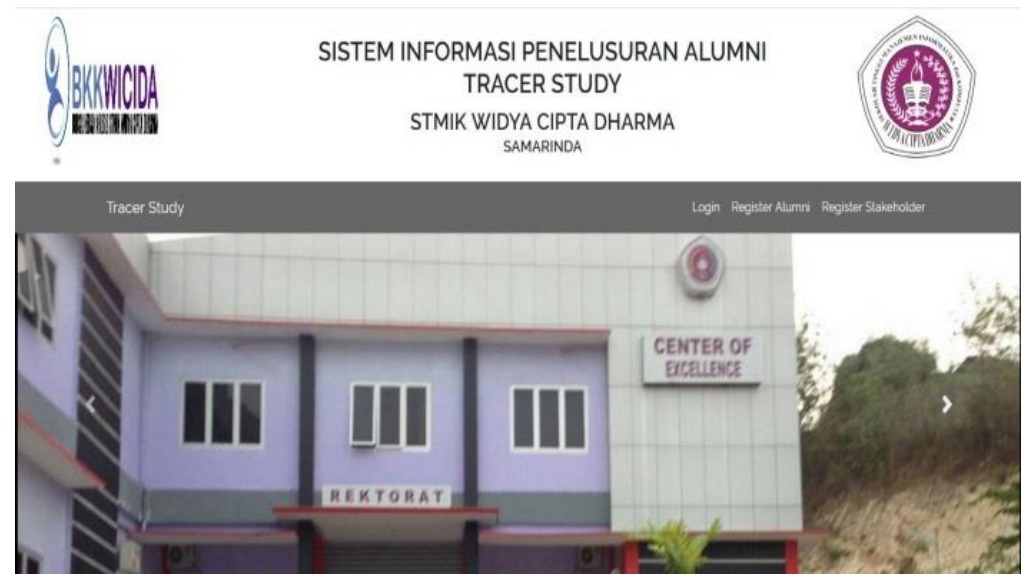

Gambar 8. Halaman Beranda

\section{b) Tampilan Halaman Register Alumni}

Pada gambar 9 merupakan tampilan dari halaman register alumni pada Sistem Infomasi Tracer study STMIK Widya Cipta Dharma. Halaman ini berfungsi menampilkan halaman registrasi bagi alumni yang telah lulus dari perguruan tinggi yang ingin mengisi kuisioner tracer study.

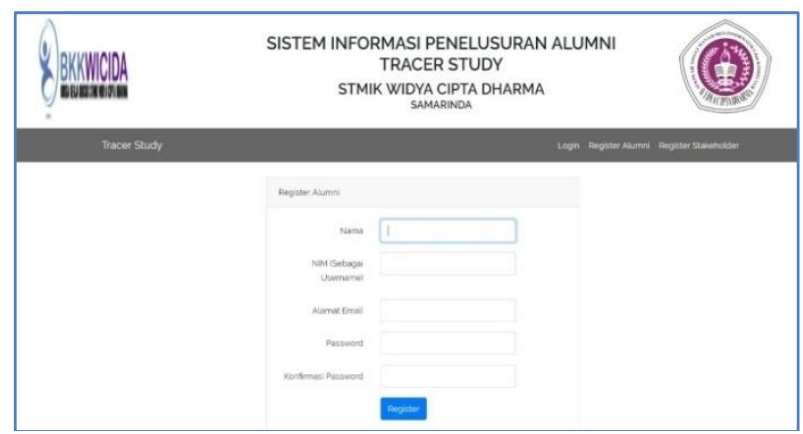

Gambar 9. Halaman Register Alumni 


\section{c) Tampilan Halaman Pengisian Kuisioner Identitas Tracer study}

Pada gambar 10 merupakan tampilan dari halaman pengisian identitas kuisioner tracer study pada Sistem Infomasi Tracer study STMIK Widya Cipta Dharma setelah alumni mengisi biodata. Otomatis halaman ini akan menampilkan halaman pengisian identitas kuisoner tracer study yang harus di isi oleh alumni.

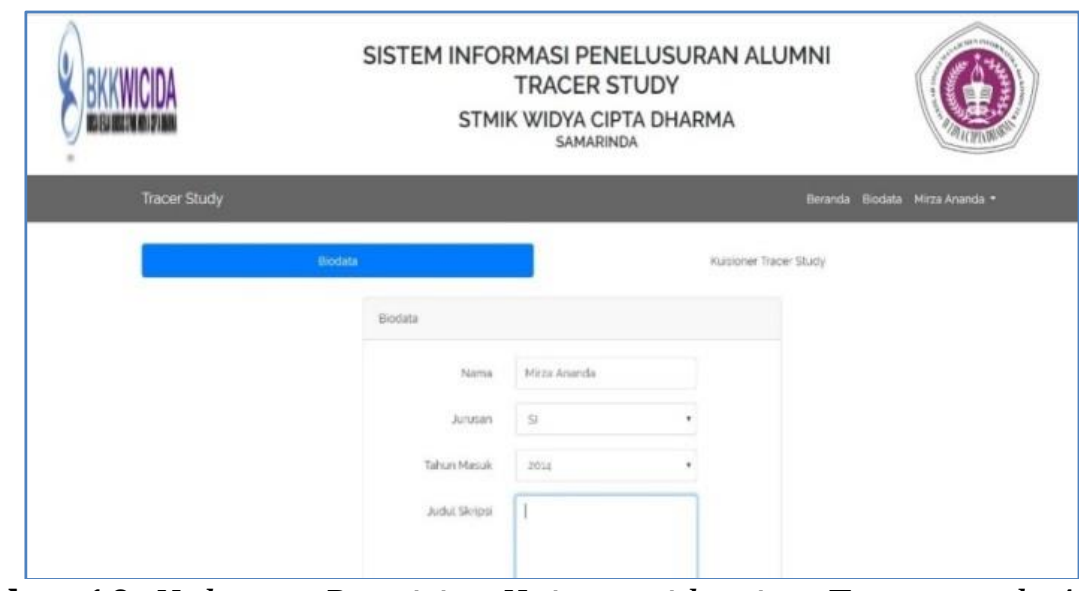

Gambar 10. Halaman Pengisian Kuisoner identitas Tracer study Alumni

\section{SIMPULAN}

Berdasarkan hasil analisa kebutuhan, rekayasa perangkat lunak dan pembangunan sistem tracer study maka dapat disimpulkan sebagai berikut :

a) Sistem Informasi Penelusuran Alumni (Tracer Study) Pada STMIK Widya Cipta Dharma Samarinda Berbasis Website dibangun dengan menggunakan bahasa pemrograman Framework Laravel, dan MySQL untuk proses penyimpanan data ke dalam database.

b) Dapat membantu BKK (Bursa Kerja Khusus) STMIK Widya CIpta Dharma Samarinda dalam melakukan pencatatan alumni dan mencatat track record alumni yang tersebar di beberapa wilayah.

c) Dapat melakukan proses pengisian kuisoner yang dapat diakses di mana saja, dan proses pengumpulan data melalui sistem infomasi Pencatatan Alumni Tracer Study lebih mudah dilakukan karena berbasis online.

d) Admin dapat mengakses data dari masing-masing alumni.

\section{DAFTAR PUSTAKA}

[1] Bambang Setia Budi., Angga Dinan A. 2015. Progress and Development of Tracer Study ITB. Poster Session presented at international conference EXLIMA 2015 on 25-26 November 2015. Bali Indonesia

[2] Sugiarti Yuni. 2013. Analisis dan Perancangan Unified Modelling Laguage (UML) Generate VB. 6. Yogyakarta: Grahallmu.

[3] Sommerville, Ian. 2011, Software Engineering. America :PenerbitAddisonWesley.

[4] S. Pressman, Roger. 2012. Software Engineering. Yogyakarta: Andi

[5] Simarmata, Janner. 2010. Rekayasa Perangkat Lunak. Yogyakarta : Andi Offset 